\title{
TAJNA NOTATKA WYDZIALU ZAGRANICZNEGO KC PPR O PROBLEMACH REPATRIACYJNYCH POLAKÓW Z ZSRR Z 5 GRUDNIA 1947 ROKU
}

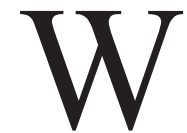

dniu 5 grudnia 1947 r. do ministra spraw zagranicznych RP Zygmunta Modzelewskiego została skierowana notatka z Komitetu Centralnego (KC) Polskiej Partii Robotniczej (PPR). List przewodni był sygnowany przez Ostapa Dłuskiego ${ }^{1}$ - dyrektora Wydziału Zagranicznego, ale w zastępstwie podpisał go inny urzędnik, prawdopodobnie (podpis jest mało czytelny) był nim Witold Sienkiewicz ${ }^{2}$. Korespondencji nadano klauzulę ,poufne”, chociaż załącznik opatrzony był adnotacją ,ściśle tajne"’3.

Niepodpisana notatka zawiera syntetyczny opis problemu licznych interwencji, zazwyczaj członków PPR, w sprawie repatriacji ich rodzin ze Związku Radzieckiego ${ }^{4}$ W dokumencie podkreślono masowość korespondencji kierowanej nie tylko do Wydziału Zagranicznego KC PPR, ale także do m.in. Ministerstwa Spraw

${ }^{1}$ Ostap Dłuski (Adolf Langer), ps. „Andre”, „Czarny”, „Jerzy”, „Malwin” (1892-1964). Działacz lewicowy i komunistyczny. Współzałożyciel Komunistycznej Partii Austrii oraz Komunistycznej Partii Galicji Wschodniej (przekształconej potem w Komunistyczną Partię Zachodniej Ukrainy). Działał także w Komunistycznej Partii Polski, Wszechzwiązkowej Komunistycznej Partii (bolszewików) - WKP(b) oraz Francuskiej Partii Komunistycznej. W latach 1945-1953 kierował Wydziałem Zagranicznym KC PPR (od 1948 r. - PZPR), a członkiem tego ugrupowania został w 1946 r. Od 1959 r. do 1964 r. był dyrektorem Polskiego Instytutu Spraw Międzynarodowych.

2 Witold Sienkiewicz, ps. „Edward Szumski”, „Margis” (1920-1990) - przed II wojną światową (i podczas niej-do 1941 r.) pracował w Wilnie jako robotnik, w latach 1942-1944 członek grupy partyzanckiej na Wileńszczyźnie (związanej z Sowietami), działacz m.in. Komsomołu, WKP(b), Komunistycznej Partii (bolszewików) Litwy, od 1946 r. członek PPR. Od 1950 r. zatrudniony w Ministerstwie Bezpieczeństwa Publicznego, w latach 1954-1956 zastępca przewodniczącego Komitetu ds. Bezpieczeństwa Publicznego, od 1956 r. pracował w Ministerstwie Spraw Wewnętrznych. W okresie 1946-1948 był instruktorem w Wydziale Zagranicznym KC PPR.

3 Archiwum Ministerstwa Spraw Zagranicznych w Warszawie (dalej: AMSZ), zespół akt: Gabinet Ministra (1945-1951) (dalej: GM), sygn. 15-18-168, Pismo kierownika Wydziału Zagranicznego KC PPR do Z. Modzelewskiego z 5 XII 1947 r., k. 232.

${ }^{4}$ Fragmenty notatki przytoczyła w swojej książce M. Ruchniewicz (s. 58), która szeroko omówiła także problem repatriacji w stosunkach polsko-radzieckich na przełomie lat 40. i 50. XX w. - M. Ruchniewicz, Repatriacja ludności polskiej z ZSRR w latach 1955-59, Warszawa 2000, s. $57-106$. 
Zagranicznych, rządu czy Ambasady RP w Moskwie. Listy zawierały opisy dramatycznych losów rodzin rozdzielonych w okresie wojny, których część członków nadal - wbrew woli własnej i bliskich - przebywała na terytorium ZSRR i pragnęła przyjechać do kraju. Dokument powstał niedługo po oficjalnym zakończeniu działalności Polsko-Radzieckiej Komisji Mieszanej ds. Ewakuacji (sierpień 1947 r.), która realizowała postanowienia porozumień repatriacyjnych z 6 lipca 1945 r., a następnie 5 marca 1947 r. Mimo danych o znacznej liczbie ludności polskiej, przebywającej w ZSRR, Moskwa zdecydowała się wygasić kwestię powrotów w relacjach z wasalnym wobec niej rządem w Warszawie ${ }^{5}$. Lato-jesien 1947 r. to - w mojej opinii - okres intensywnej „stalinizacji” dyplomacji „ludowej” Polski, szczególnie jeśli weźmiemy pod uwagę jej relacje z Kremlem. Wyraźne symptomy tego procesu, którego istotną częścią były sprawy repatriacyjne, pojawiły się już rok wcześniej - wraz z usunięciem z funkcji ambasadora RP w ZSRR prof. Henryka Raabego, który otwarcie mówił o tym, że w ZSRR żyły tysiące Polaków potrzebujących wsparcia materialnego, właściwego uregulowania ich statusu i opieki prawnej, a przede wszystkim oczekujących na repatriację.

Notatka Wydziału Zagranicznego KC PPR była wyraźnym głosem ze strony dominującej w Polsce partii, że problem przyjazdów i powrotów obywateli polskich ze Wschodu wciąż jeszcze nie był rozwiązany. Była ona o tyle istotna, że obok innych, całkiem licznych dokumentów różnych instytucji, jakie powstały w tamtym czasie i dotyczyły repatriacji, notatka z grudnia 1947 r. była opinią płynącą wprost z Komitetu Centralnego PPR, a zatem partyjnego kierownictwa. Wskazywano w niej i piętnowano brak skuteczności w załatwianiu spraw repatriacji (szczególnie rodzin członków PPR) Ministerstwa Spraw Zagranicznych i Ambasady RP w Moskwie, co może sugerować „tarcia” pomiędzy aparatem partyjnym i dyplomatycznym, chociaż - jak wiadomo - to partia była faktycznym krajowym ośrodkiem decyzyjnym w stosunku do rządu (nie licząc głosu Kremla, który podejmował decyzje za pośrednictwem swoich przedstawicieli nad Wisłą oraz „po linii partyjnej”)'.

W notatce zdawkowo wyszczególniono kategorie osób represjonowanych przez Sowietów podczas wojny i po jej zakończeniu. Do listy „przestępstw”, których mieli dopuścić się obywatele polscy, zaliczono m.in. bycie „podejrzanym politycznie". Użycie tego sformułowania powielało kuriozalną oskarżycielską retorykę stosowaną przez radzieckiego okupanta wobec Polaków na zajętych przez Armię Czerwoną terenach II Rzeczypospolitej. Komitet Centralny PPR (a następnie także PZPR) przejmował zatem bolszewicki sposób myślenia, że

${ }^{5}$ O działalności Komisji patrz m.in. w: Polska Delegacja w Polsko-Radzieckiej Komisji Mieszanej Do Spraw Ewakuacji. Wybór dokumentów (1945-1947), wstęp i oprac. W. Marciniak, [Łódź 2016].

' Por.: J. Wrona, System polityczny w Polsce w latach 1944-1948, „Pamięć i Sprawiedliwość” 2005, $\mathrm{nr} 4 / 2(8)$, s. 54. 
samo podejrzenie o nieprawomyślność polityczną było wystarczającym powodem do zastosowania dotkliwych represji.

Autor lub autorzy notatki odnieśli się także do osób, które nie repatriowały się we właściwym (tj. określonym porozumieniami) czasie. Wiele z nich miało - zdaniem partyjnych funkcjonariuszy - nie powrócić do Polski wyłącznie z własnej winy. Ta opinia, jak również użyte w tekście sformułowania, bardzo przypominają raport końcowy z działalności Polskiej Delegacji w Komisji Mieszanej ds. Ewakuacji z 1 września 1947 r. autorstwa Mariana Naszkowskiego - ówczesnego ambasadora RP w ZSRR ${ }^{7}$. Zapewne raport ten był znany w Wydziale Zagranicznym KC PPR i być może wzorowano się na nim. W omawianej notatce szerzej „wyjaśniono” jednak przypuszczalne powody zwłoki Polaków w ZSRR w podjęciu decyzji o wyjeździe do kraju. Miały nimi być m.in. oczekiwania na zmianę wschodniej granicy Polski (odzyskanie przez nią Kresów Wschodnich II RP), a nawet liczenie na kolejny światowy konflikt. Nastroje te miały być wywołane przez „propagandę wrogów Polski Demokratycznej”.

Główna myśl zawarta w notatce to oczywiście konieczność kontynuowania akcji repatriacyjnej ludności polskiej z ZSRR. Charakterystyczne dla tamtych czasów są jednak powody, jakie wskazano w dokumencie. Nie należała do nich powinność państwa wobec własnych obywateli polegająca na udzielaniu im pomocy w przyjeździe do ojczyzny, ale troska o dobre relacje ze Związkiem Radzieckim - politycznym protektorem i gwarantem władz partyjno-rządowych, jakie zostały zainstalowane w Polsce po II wojnie światowej. Taki punkt widzenia szedł w parze z poglądami na sprawy Polaków na Wschodzie przedstawicieli dyplomacji. Kilkanaście miesięcy po powstaniu notatki - 19 lutego 1949 r. - Wanda Michalewska (kierowniczka Wydziału Konsularnego Ambasady RP w Moskwie) udzielając odpowiedzi Wydziałowi do Spraw Polonii Zagranicą MSZ w sprawie przesyłania sprawozdań o potrzebach Polaków przebywających poza granicami państwa, lakonicznie zakomunikowała, że:

w ZSRR nie ma Polonii w tym rozumieniu, jak ona istnieje w innych państwach i w konsekwencji tutejsza placówka nie może rozwijać działalności na odcinku polonijnym, ani prowadzić sprawozdawczości o potrzebach Polonii w ZSRR .

W dokumentacji wytworzonej przez aparat MSZ od końca lat 40. XX w. dość wyraźnie akcentowano, że w Związku Radzieckim nie było Polonii - czyli mniejszości polskiej, którą należałoby objąć opieką, a dość niechętnie oficjalnie przyznawano, że Polacy w ogóle tam żyli na stałe - jako grupa narodowa. Wiosną

${ }^{7}$ Polska Delegacja..., s. 149. Warto dodać, że niemal identycznymi słowami konkludował swoje sprawozdanie z działalności Polskiej Delegacji jej ostatni przewodniczący - Aleksander Juszkiewicz. Por.: tamże, s. 162.

${ }^{8}$ AMSZ, zespół akt: Biuro Konsularne, sygn. 20-5-71, Pismo W. Michalewskiej do Wydziału do Spraw Polonii Zagranica MSZ z 19 II 1949 r., k. 1; Por. M. Ruchniewicz, dz. cyt., s. 55. 
1948 r. W. Michalewska powiadomiła MSZ (Biuro Konsularne), że Ambasada RP w Moskwie nie zamierzała przeprowadzić rejestracji obywateli polskich mieszkających w ZSRR, gdyż nie miało to „praktycznego znaczenia”. Michalewska wyjaśniała, że na terenie ZSRR przebywały nieliczne grupy obywateli polskich, a mianowicie: pracownicy Ambasady RP (36 osób), pracownicy Biura Radcy Handlowego (13 osób), pracownicy Konsulatu RP w Kijowie (sześć osób), pracownicy Polskiej Agencji Prasowej (trzy osoby), studenci uczący się w radzieckich uczelniach (34 osoby). Liczną ludność polską żyjącą w ZSRR - czy to na wolności, czy też w warunkach więziennych lub obozowych (w zdecydowanej większości wszyscy ci ludzie byli obywatelami II RP, którym Związek Radziecki bezprawnie narzucił swoje obywatelstwo) - kierowniczka Wydziału Konsularnego moskiewskiej placówki uznawała wyłącznie za „poddanych” radzieckich i nie dostrzegała (przynajmniej oficjalnie) ich rzeczywistego pochodzenia i powodów pobytu w ZSRR?

Mimo istnienia takich poglądów, jak ten przytaczany powyżej, problem repatriacji - choć celowo wygaszany - nadal istniał w relacjach Warszawa-Moskwa na przełomie lat 40. i 50. XX w. Prezentowany dokument jest przykładem na to, że temat powrotów/przyjazdów Polaków z ZSRR był na porządku dziennym gremiów partyjnych czy też rządowych, jednak - niestety - do czasu wznowienia akcji repatriacyjnej w połowie lat 50. XX w. ograniczona działalność interwencyjna dyplomacji na rzecz ludności polskiej w ZSRR była skazana na niepowodzenie.

$$
* * *
$$

W publikowanym poniżej dokumencie poprawiono błędy ortograficzne, uzupełniono interpunkcję, ujednolicono zapisy dat oraz uwspółcześniono pisownię. Wszelkie dokonane zmiany i ingerencje nie zmieniają jego sensu i mają charakter edytorski. Wyróżnienia zostały oddane zgodnie z oryginałem, tzn. poprzez podkreślenie fragmentu tekstu. Dopisania i uzupełnienia zostały ujęte w nawias kwadratowy.

${ }^{9}$ Tamże, sygn. 20-18-208, Pismo W. Michalewskiej do Biura Konsularnego MSZ z 30 III 1948 r., k. 39-40. 
$\underline{\text { Ściśle Tajne }}$

Wydział Zagraniczny

KC PPR

\section{Informacja \\ w sprawie wpływajacych do Wydziału Zagranicznego podań o repatriacje rodzin $\mathrm{z}$ ZSRR}

Do Wydziału Zagranicznego KC wpływają stale podania, przeważnie [od] towarzyszy - członków partii z różnych województw kraju, z prośbą o udzielenie pomocy w repatriowaniu członków ich rodzin do Polski.

O ile w okresie początkowym (listopad 1946 r. - czerwiec 1947 r.) wpływały prośby o interwencje w sprawach wyjątkowych, niemogących znaleźć pozytywnego załatwienia sprawy w instytucjach bezpośrednio kierujących repatriacją, to w ostatnich miesiącach przybiera to charakter niemal masowy. Należy podkreślić, że prośby wpływające do Wydziału Zagranicznego są tylko małym odsetkiem podobnych próśb kierowanych czy to do Kancelarii Prezydenta RP, czy to do Urzędu Generalnego Pełnomocnika RP do Spraw Repatriacji, do Prezydium Rady Ministrów, MSZ i również do Ambasady Radzieckiej w Warszawie.

W chwili obecnej wzmożony napływ podań [dotyczących] członków rodzin, które przebywają jeszcze w ZSRR, tłumaczy się zakończeniem działalności polskich placówek repatriacyjnych na terenie ZSRR i Polsko-Radzieckiej Komisji Mieszanej. Pozostające tam rodziny zwracają się do swych krewnych przebywających w kraju, aby tutaj starali się o ich sprowadzenie do Polski.

Wpływające podania, oprócz spraw represjonowanych w latach 1939-1945 za różnego rodzaju przestępstwa, jak: pobranie łapówek podczas pełnienia funkcji administracyjnych, kradzież, podejrzani politycznie itp., dotyczą przeważnie osób, które nie repatriowały się we właściwym terminie, tzn. w czasie trwania umowy o repatriacji. Należy stwierdzić, że część z nich nie repatriowała się we właściwym terminie jedynie $\mathrm{z}$ własnej winy ulegając szeptanej propagandzie wrogów Polski Demokratycznej, którzy nakazywali czekać, nie repatriować się, ponieważ ,jeszcze granice nie są ustalone, będzie wojna" itp.

Jednak znaczna ilość osób nie wróciła do kraju z przyczyn od siebie niezależnych, jak: poważne wypadki choroby, zakończenie studiów w uczelniach radzieckich lub brak wiadomości od ojców rodzin, którzy w pierwszych dniach po wyzwoleniu wstąpili do Wojska Polskiego i przebywali na froncie nie mając kontaktu z rodziną, lub tych, którzy przebywali w obozach niemieckich i po wyzwoleniu znaleźli się w Polsce, wówczas gdy ich rodziny nie mając od nich wiadomości nie chciały same decydować się na repatriację. Są też wypadki, kiedy 
rodziny naszych towarzyszy z różnych powodów repatriowały się z Polski do ZSRR, obecnie zaś pragną wrócić do kraju.

Należy nadmienić, że Wydział Zagraniczny w każdej poważniejszej sprawie interweniował w Ambasadzie RP w Moskwie, jednak bezskutecznie. Często na nasze pisma otrzymywaliśmy odpowiedzi, że: ,wystosowano notę”; „wniesiono na listę"; , ,przyjazd do kraju nastąpi w miesiącu lipcu”, itp., jednak fakt pozostaje faktem, że ani jeden człowiek na naszą interwencję do kraju nie wrócił (nie biorąc pod uwagę spraw związanych z 1937 r., załatwianych poza Ambasadą), chociaż niektóre wypadki bezwzględnie zasługiwały na pozytywne załatwienie. Np. tow. Wołodźko z Ciechanowa, który po powrocie z obozu niemieckiego został powiadomiony, że żona jego zginęła tragicznie na ulicach Wilna przejechana przez samochód, zwrócił się do nas z prośbą o sprowadzenie swego dziewięcioletniego synka, który został u obcych ludzi. Pomimo naszej interwencji i odpowiedzi Wydziału Konsularnego Ambasady RP w Moskwie, że dano polecenie do Wilna, dziecko do kraju nie wróciło.

Na podstawie codziennych rozmów z petentami zgłaszającymi się do Wydziału Zagranicznego w sprawie repatriowania ich rodzin i po zapoznaniu się z napływającymi podaniami należy stwierdzić, że w Polsce znajduje się bardzo dużo rodzin rozłączonych, przeważnie na skutek działań wojennych, które wszelkimi możliwymi drogami starają się o sprowadzenie swych bliskich składając podania do wszystkich możliwych urzędów. Rzecz jasna, że nie znajdując nigdzie pozytywnego załatwienia sprawy, panuje wśród nich uczucie goryczy wobec Zwiazku Radzieckiego i nieufność do Rządu Polskiego, czemu dają wyraz w rozmowach i podaniach. Bywają też wypadki, kiedy osoby niemogące sprowadzić swoich rodzin zgłaszają się do Urzędu Gen.[eralnego] Pełnomocnika z prośbą o wyjazd z powrotem do ZSRR, do rodziny. Zauważa się również przygnębienie i rozczarowanie wśród naszych towarzyszy partyjnych, którzy zwracając się do Komitetu Centralnego liczą, że ich prośby zostaną przychylnie załatwione, jednak niestety i ta droga nie odnosi skutku.

Oto kilka charakterystycznych cytatów z podań petentów: tow. Jakubowski, nauczyciel z Gniewkowa (pow. Inowrocław), zapytuje o właściwą drogę postępowania celem sprowadzenia żony zza Bugu i pisze:

...zwracam się do MSZ, które sprawę skierowało do PUR-u. Na interwencję Ministerstwa Adm.[inistracji] Publ.[icznej] 13 czerwca 1946 r. podanie zostało przesłane do Moskwy. Do dnia dzisiejszego żadnej odpowiedzi nie otrzymałem.

I zaznacza, że żona jego, narodowości rosyjskiej, zamieszkiwała stale w Polsce. Rozłączyła ich wojna, ponieważ tow. Jakubowski w 1941 r. został powołany do wojska, gdzie przebywał do 1945 r. Pisze dalej: 
...pięć lat walczyłem o wolność. Dzisiaj jako były żołnierz i obecny członek PPR z całą świadomością twierdzę, że obowiązek wobec państwa wypełniłem. Niechże więc państwo wykona swój obowiązek wobec żołnierza i obywatela. Dla mnie, jako przeciętnego obywatela, trudno zrozumieć, aby przy tak serdecznych stosunkach Polski i ZSRR to było aż tak trudne do przeprowadzenia. Czy moja żona nie ma praw nawet żon - Włoszek czy Angielek?

Tow. Zielińska, nauczycielka z Siemianowic Ś1.[ąskich], stara się o sprowadzenie rodziców - staruszków ze Lwowa. Sama wyjechała wcześniej po zorganizowanym na nią napadzie przez NSZ-towców. W jednym z pięciu podań zaadresowanych do tow. Wiesława ${ }^{10}$ pisze:

...3 sierpnia 1946 r. podanie moje w Urzędzie Repatriacyjnym tak długo załatwiali, że upłynął czas repatriacji ze Wschodu. Od 31 grudnia 1946 r. podanie moje [znajduje się] w Wydziale Radzieckim MSZ, od 31 grudnia 1946 r. zgłoszenie do PCK. Ojciec mój cieszył się każdym zwycięstwem Armii Czerwonej, ani jednej godziny nie pracował u okupanta. Dziś jestem ich jedyną żywicielką i podporą starości, rodzice żyją na łasce obcych, zamiast u córki.

Kom.[itet] Pow.[iatowy] PPR w Bolesławcu zwrócił się do Wydziału Zagranicznego o dopomożenie w sprowadzeniu z Ukrainy żony i dziecka tow. Czarnobaja Lucjana przesyłając o nim opinię:

Tow. Czarnobaj cieszy się u nas jak najlepszą opinią i jest prawdziwym, szczerym demokratą, mogąc służyć za wzór innym. Towarzysz nasz jest zniechęcony do życia, ponieważ, jak sam twierdzi, nie wie, czy jest kawalerem czy żonatym. Nie mając domowego ogniska, a będąc wysyłanym z miejsca do miejsca i nie uzyskawszy żadnej nadziei co do powyższej sprawy, zwraca się do nas z ostatnią prośbą,

Tow. Czarnobaj dodaje od siebie:

...dostaję listy od żony bardzo często, w których mnie prosi o jak najszybszy powrót tutaj do mnie. Tak żyć dalej, jak obecnie, z naprężonymi nerwami i myślami, nie mogę, ponieważ jestem ojcem i mężem, na którego sumieniu ciąży los i odpowiedzialność jako sumiennego i moralnego człowieka.

\section{Załącza też list żony, która pisze do męża:}

...Drogi mężu, może jakimś cudem da się zrobić, że ja się jakoś dostanę do Ciebie. Już prędko będzie trzy lata naszej kochanej córeczce, która tak ładnie mówi, że jutro nasz tatuś przyjedzie.

\section{Bezpartyjny ob. Rodziewicz, pracownik PKP w Siedlcach, pisze:}

Jako do najwięcej popularnej partii cieszącej się w większości narodu polskiego największym zaufaniem i poparciem zwracam się z wielką prośbą o wyjaśnienie sprawy związanej z repatriacją Polaków z ZSRR. Rodzice moi posiadają obywatelstwo polskie. Swego czasu zarejestrowani byli na wyjazd do Polski, dokąd mieli wyjechać w miesiącu kwietniu

${ }^{10}$ Chodzi o Władysława Gomułkę - wówczas I sekretarza KC PPR. 
1946 r., ale chwilowe zachorowanie ojca nie pozwoliło wyjechać w miesiącu kwietniu, natomiast począwszy od miesiąca maja 1946 r. repatriacja została wstrzymana (obwód brzeski). Zaznaczam, że sam osobiście będąc w Warszawie złożyłem podanie o wysłanie zapotrzebowania w Sekretariacie Generalnego Pełnomocnika do Spraw Repatriacji w dniu 3 stycznia br. Również brat wysłał podanie przez sekcję pol.[ityczno]-wych.[wychowawczą] z jednostki wojskowej Nr 2875 ,a” w Przemyślu. Obiecano mi, że odpowiedź otrzymam za parę tygodni. Informowałem się również w PUR-ze w Siedlcach, który nie mógł udzielić mi żadnej konkretnej odpowiedzi. Czekając odpowiedzi nie parę tygodni, a parę miesięcy, wysłałem znowu 24 kwietnia 1947 r. podobne podanie do Gen.[eralnego] Pełn.[omocnika] Do Spraw Repatriacji z zaznaczeniem o wysłaniu poprzedniego i z prośbą o jakąkolwiek odpowiedź. Dotychczas ja, jak i brat nie dostaliśmy żadnej odpowiedzi.

Podobnych wypadków można przytoczyć wiele.

Jak wynika z całokształtu spraw związanych z repatriacją należy stwierdzić, że w chwili obecnej w kraju nie ma urzędu, który mógłby wskazać petentom właściwą drogę załatwienia podobnych spraw. Zainteresowani nie mogą uzyskać informacji, czy sprawy repatriacji są możliwe jeszcze do załatwienia, jakie dokumenty i gdzie należy składać.

Urząd Generalnego Pełnomocnika do Spraw Repatriacji przyjmuje podania od petentów i przeważnie zawiadamia, że sprawę skierowano do załatwienia w Ambasadzie RP w Moskwie. Podobne zawiadomienia, z datą sprzed sześciu lub więcej miesięcy, dotyczące spraw dotychczas niezałatwionych, przedstawiali towarzysze zgłaszający się do Wydziału Zagranicznego. Podobne zawiadomienia wysyła również Wydział Radziecki MSZ, który nadal przyjmuje podania uważając, że po utworzeniu Konsulatu RP w Wilnie, Kijowie i Mińsku „da się coś zrobić".

Ministerstwo Bezpieczeństwa Publicznego starało się załatwić sprawy swoich pracowników przez Urząd Gen.[eralnego] Pełn.[omocnika] Do Spraw Repatriacji. Pracownicy mający rodziny w ZSRR złożyli podania, jednak i ta droga załatwienia dotychczas nie dała rezultatów. Osoby pragnące sprowadzić swych krewnych zwracając się do urzędów kierujących repatriacją wydostają najróżniejsze dokumenty stwierdzające czy to ich obywatelstwo polskie, czy to dowód zamieszkania w Polsce przed rokiem 1939, opinie partii politycznych, urzędów lub osób znających ich przed wojną, listy, depesze od krewnych itp.

Np. tow. Awęcki Adam, sekretarz Kom.[itetu] Powiatowego PPR w Myśliborzu, składając podanie do Wydziału Zagranicznego z prośbą o interwencję i sprowadzenie swej represjonowanej żony znajdującej się obecnie ${ }^{11} \mathrm{w}$ ZSRR załączył, nie wiedzieć po co, opinie odnośnie jego osoby Komitetów Powiatowych PPS, SL, SD, Powiatowej Rady Narodowej, odpis metryki, wyciąg z ksiąg meldunkowych, akta ślubu itp. Można przyjąć, że tematem dnia w Myśliborzu jest żona tow. Awęckiego.

\footnotetext{
${ }^{11}$ Dopisano ręcznie.
} 
Tow. Najman z Dzierżoniowa, która udała się do Wydziału Radzieckiego MSZ w sprawie sprowadzenia syna, otrzymała w listopadzie br. wypisany przez urzędniczkę Wydziału Radzieckiego porządkowy spis właściwego postępowania w celu otrzymania „listu gwarancyjnego”, który ma być niezbędny dla pomyślnego załatwienia sprawy powrotu syna do kraju.

Spis ten wygląda następująco:

1. Dwóch świadków do notariusza, żeby spisać akt obywatelstwa polskiego syna.

2. Do Min.[isterstwa] Administracji Publicznej - inspektor Orzechowski, pokój 125, Rakowiecka nr 4, Warszawa.

3. Przetłumaczyć na język rosyjski - p. Kostro, ul. Hoża 27 m. 4 (400 zł).

4. Sąd Okręgowy - Warszawa, ul. Leszno 53/54, trzecie piętro. Sekretariat Prezydialny (50 zł).

5. Ministerstwo Sprawiedliwości (ul. 6 Sierpnia nr 30, pokój 306 - 50 zł).

6. Min.[isterstwo] Spraw Zagranicznych - Biuro Konsularne, Ref.[erat] Prawny, trzecie piętro, pokój 153 (50zł).

7. Konsulat ZSRR - Warszawa, Al. Szucha 9 (433 zł).

Robić w dwóch egzemplarzach.

Podane kolejno urzędy miały zalegalizować „list gwarancyjny”, przyłożyć pieczęcie, podpisać, po czym należało to złożyć w Wydziale Radzieckim MSZ.

W ten sposób [po]informowani interesanci przyjeżdżają do Warszawy, tracą czas i wydają pieniądze na podróż, nocleg i najróżniejsze opłaty stemplowe, chociaż Wydziałowi Radzieckiemu wiadomym jest, że z chwilą zakończenia działalności Polsko-Radzieckiej Komisji Mieszanej wysyłanie podobnych listów do Moskwy, które przedtem były niezbędne dla zrzeczenia się obywatelstwa radzieckiego i nabycia polskiego, obecnie w niczym nie zmieniają sytuacji, ponieważ Urzędy Pełnomocnika RP do Spraw Repatriacji na terenie ZSRR zostały zlikwidowane.

Tymczasem w prasie od czasu do czasu podaje się wiadomości o przybywaniu transportów z repatriantami z ZSRR. Osoby oczekujące swoich krewnych nie wiedzą, że transporty te nie dotyczą osób przebywających na wolności, przewożą zaś byłych internowanych, przeważnie AK-owców oraz autochtonów, którzy powołani przez okupanta do wojska niemieckiego trafili do niewoli radzieckiej, a którzy to obecnie zostają zwolnieni na podstawie zawartej pomiędzy delegacjami Rządów RP i ZSRR umowy w marcu br.

Jasnym jest, że ci wszyscy, którzy mają swoje matki, żony lub dzieci w ZSRR, nigdy o nich nie zapomną i długie lata będą interweniować we wszystkich możliwych urzędach, dopóki nie znajdą się ze swoimi rodzinami.

Zrozpaczeni kilkuletnią rozłąką ze swoimi bliskimi opowiadają o swych żalach w miastach, miasteczkach i wsiach, w pociągach, autobusach i tramwajach, poważnie szkodząc zbliżeniu polsko-radzieckiemu. 
Wobec takiego stanu rzeczy uważamy, że niezbędnym jest specjalne zainteresowanie się sprawą repatriacji przez kierownictwo naszej Partii.

Niewątpliwie po odpowiednim przedstawieniu sprawy towarzyszom radzieckim, którzy mają duże zrozumienie dla szkodliwości tego rodzaju szeptanej propagandy „rodzinnej” dla zbliżenia polsko-radzieckiego, znajdą się sposoby dla pozytywnego załatwienia tych spraw.

Źródło: AMSZ, GM, sygn. 15-18-168, k. 233-238, oryginał, mps.

\section{Wojciech Marciniak}

\section{SECRET NOTE OF THE FOREIGN DEPARTMENT OF CENTRAL COMMITTEE OF POLISH WORKERS' PARTY CONCERNING REPATRIATION PROBLEMS OF POLES FROM THE USSR DATED DECEMBER 5 ${ }^{\text {TH }}, 1947$}

$\operatorname{In}^{\mathrm{D}}$ December of 1947 in Foreign Department of Central Committee of Polish Workers' Party appeared a note concerning difficulties with repatriation of Poles from the USSR. They concerned mainly relatives of members of the ruling party. The note contains descriptions of many formal problems concerning arrival of Polish citizens from the USSR. The document was created when the question of repatriation in Polish-Soviet relations was in fact frozen. Nonetheless, the problems described in the document prove that repatriation remained important issue for communist party in Poland.

Słowa kluczowe: repatriacja, deportacja, przesiedlenie, zesłanie, stosunki polsko-radzieckie

Keywords: repatriation, deportation, resettlement, exile, Polish-Soviet relations

\section{BIBLIOGRAFIA}

\section{Źródła archiwalne:}

Archiwum Ministerstwa Spraw Zagranicznych w Warszawie

Biuro Konsularne.

Gabinet Ministra (1945-1951).

\section{Źródla publikowane:}

Polska Delegacja w Polsko-Radzieckiej Komisji Mieszanej Do Spraw Ewakuacji. Wybór dokumentów (19451947), wstęp i oprac. W. Marciniak, [Łódź 2016].

\section{Opracowania:}

Ruchniewicz M., Repatriacja ludności polskiej z ZSRR w latach 1955-59, Warszawa 2000.

Wrona J., System polityczny w Polsce w latach 1944-1948, „Pamięć i Sprawiedliwość” 2005, nr 4/2 (8). 